\title{
Use of Organic Acids and A Competitive Exclusion Product as Growth Promoter and Salmonella Enteritidis Control in Commercial Turkeys
}

\section{-Author(s)}

\author{
Milbradt EL \\ Okamoto AS \\ Padovani CR \\ Fascina VB \\ Silva TM' \\ Altarúgio R \\ Hataka A \\ Schmidt EMS \\ Andreatti Filho RL'
}

Department of Veterinary Clinical Sciences, School of Veterinary Medicine and Animal Science, Universidade Estadual Paulista "Júlio de Mesquita Filho" (UNESP), Botucatu, São Paulo, Brazil.

" Department of Biostatistics, Institute of Biosciences, Universidade Estadual Paulista "Júlio de Mesquita Filho" (UNESP), Botucatu, São Paulo, Brazil.

\section{ABSTRACT}

It is estimated that Salmonella causes one million illnesses in the United States annually, with 19,000 hospitalizations and 380 deaths. There are various serotypes of this bacterium, and the serotypes Typhimurium and Enteritidis are commonly isolated from outbreaks and, in most cases, present resistance to the antibiotics utilized in clinical medicine. One of the current theories to explain the emergence of bacterial resistance is the continuous use of antibiotics as growth promoters in animal feeds. Despite the lack of evidences that antibiotic growth promoters cause bacterial resistance, the poultry industry has explored strategies to reduce or to eliminate the use of antibiotic growth promoters in the production chain, including the improvement of biosecurity programs, use of vaccines, genetic selection, and the feeding of other additives, such as organic acid blends (OAB) and competitive exclusion (CE) products. This study aimed at evaluating the effect of the continuous dietary supplementation of an $O A B$ and a $C E$ product on the growth performance, $\mathrm{pH}$ of the crop and cecal contents, control of Salmonella Enteritidis (SE) in the cecal content, and acutephase protein serum levels in starter commercial turkeys. The additives promoting similar results as antibiotics under controlled experimental conditions should be further evaluated on commercial farms to allow their utilization under practical conditions. Supplementing commercial turkey diets with the evaluated $O A B$ and $C E$ product may reduce SE load. Serum OVT and AGP levels can be used as effective and fast indicators of infection, including that by SE.

\section{INTRODUCTION}

By the end of the 1980s, the consumption of poultry meat started to significantly increase due to health concerns by the consumers, who search for foods with lower fat content, and turkey meat is an excellent option in this sense. Despite being nutritionally healthy, poultry meat is one main sources of human infections by Salmonella. Among the different serotypes of Salmonella, Enteritidis is one of the most commonly isolated in salmonellosis outbreaks, and it is frequently associated with the consumption of poultry products. According to the Centers for Diseases Control and Prevention (2014), the incidence of Enteritidis infection was lower in 2013 relative to 2010-2012, but not to 2006-2008. Furthermore, in 2011, about 5\% of Salmonella tested by the CDC were resistant to five or more types of drugs (CDC, 2013). The use of antibiotics in animal feeds as growth promoters is among the many theories to explain the emergence of bacterial resistance (Dibner \& Richards, 2005). The poultry industry has developed strategies to reduce the use of antibiotics in meat production, which include improving security programs, the use of vaccines, genetic selection pressure, and feeding additives such as probiotics, organic acid blends 
Milbradt EL, Okamoto AS, Padovani CR, Fascina VB, Silva TM, Altarúgio R, Hataka A, Schmidt EMS, Andreatti Filho RL
Use of Organic Acids and A Competitive Exclusion Product as Growth Promoter and Salmonella Enteritidis Control in Commercial Turkeys
$(\mathrm{OAB})$, prebiotics, and competitive exclusion (CE) products (Sun et al., 2005).

Competitive exclusion has been utilized as a prophylactic measure to increase the resistance of birds to infections by bacteria belonging to the genus Salmonella, and, according to Schneitz (2005), this is the most efficient and harmless method available to control intestinal disorders in poultry, since it consists of a biological treatment, which does not leave residues. In addition of providing protection against pathogenic agents, CE may also exert a positive influence on the performance of poultry (Goren et al., 1984).

Feeding organic acids can reduce in the number of bacteria of the Enterobacteriaceae family in the intestinal tract. According to Van Immerseel et al. (2006), these compounds are efficient against Salmonella spp., preventing its growth by changing the $\mathrm{pH}$ of the medium or inhibiting the genetic expression of some virulence factors of this bacterium.

This study aimed at evaluating the effect of the continuous dietary supplementation of $\mathrm{OAB}$ and of a CE product on the growth performance, $\mathrm{pH}$ of the crop and cecal contents, on the control of Salmonella Enteritidis (SE) in the cecal content, and acute-phase protein serum concentrations of commercial turkeys during the starter rearing phase.

\section{MATERIALS AND METHODS}

The experimental protocol was approved by the Ethics Committee on Animal Use of the Universidade Estadual Paulista "Júlio de Mesquita Filho" (Number 177/2012). Euthanasia of the turkey poults was performed via intramuscular administration of $2 \mathrm{mg}$ xylazine/kg body weight, followed by intravenous administration of $15 \mathrm{mg}$ sodium thiopental/kg body weight. After birds were deemed to be unconscious, $1.5 \mathrm{~mL}$ of potassium chloride $(\mathrm{KCl})$ was administered to induce death (AVMA, 2007).

\section{Strain of Salmonella Enteritidis and Oral Salmonella Challenge Protocol}

The strain of Salmonella Enteritidis (phage type 4) used in this experiment was isolated from a turkey farm, and was selected for nalidixic acid (Nal) and rifampicin (Rif) resistance by successive passages in Brilliant Green Agar (BGA) containing Nal (100 $\mu \mathrm{g} / \mathrm{mL})$ and Rif $(100 \mu \mathrm{g} / \mathrm{mL})$, as described by Andreatti Filho et al. (1997).

The challenge inoculum consisted of SE cultures grown in Brain Heart Infusion Broth (BHIB) at $41^{\circ} \mathrm{C}$ for $18 \mathrm{~h}$. Serial dilutions in phosphate-buffered saline solution (PBS); $\mathrm{pH}$ 7.2) were used to determine the number of colony-forming units (CFU). All bacterial counts were performed by plating $0.1 \mathrm{~mL}$ of the culture (BHIB) and the serial dilutions (PBS) in duplicate on brilliant green agar (Nal/Rif). The plates were incubated at $41^{\circ} \mathrm{C}$ for $24 \mathrm{~h}$, and the CFU of SE were determined.

All birds, except for those in in the Negative Control group, were individually inoculated via oral gavage with one dose of $3.8 \times 10^{8}$ CFU of SE at $18 \mathrm{~d}$ of age.

\section{Birds and Experimental Facilities}

A total of 100 one-day-old female hybrid commercial (BUT Big 9, British United Turkeys) turkey poults were obtained from a private hatchery. The poults were vaccinated at the hatchery against Newcastle disease and turkey infectious rhinotracheitis. In order to ensure that the poults were not previously infected with SE, meconium was collected upon arrival, and 15 poults were sacrificed for subsequent Salmonella sp. tests using the methodology proposed by Mallinson \& Snoeyenbos (1989).

The poults were randomly allotted to groups of five poults each to each of the 20 cages $(0.69 \mathrm{~m} \times 0.99 \mathrm{~m} \times$ $0.96 \mathrm{~m}$ ), with four cages per treatment. Housing, feed management, and daily care procedures were similar for all birds, and followed the recommendations of Aviagen (2015). Poults were initially maintained at $32^{\circ} \mathrm{C}$, and the temperature was gradually reduced by $3^{\circ} \mathrm{C}$ per wk to $21^{\circ} \mathrm{C}$ by the end of wk 4 .

Birds were fed starter ( 0 to $3 \mathrm{wk}$ ) and grower ( 3 to 4 wk) diets based on corn and soybean meal. The trial lasted $28 \mathrm{~d}$. Water and feed were supplied ad libitum. The experimental diets were formulated to meet or exceed the minimum nutrient requirements of turkeys according to the NRC (1994) (Table 1). Dietary amino acid content was formulated on a total amino acid basis, and was kept constant among the diets. The starter diet was offered as $2.0-\mathrm{mm}$ pellets, and the grower diet as 6.0-mm pellets.

All treatment groups were subjected to the same biosecurity measures. Mortality was monitored daily.

\section{Experimental Diets and Additives}

The poults were housed and distributed according to a completely randomized design into five treatments with four replicates of five birds each $(n=20)$. The treatments consisted of: Negative Control (not challenged): birds fed the basal diet not supplemented with additives and not challenged with SE; Positive Control (challenged): birds fed the basal 
Milbradt EL, Okamoto AS, Padovani CR, Fascina VB, Silva TM, Altarúgio R, Hataka A, Schmidt EMS, Andreatti Filho RL

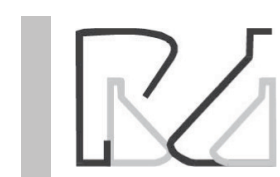

Table 1 - Composition of the basal diets

\begin{tabular}{|c|c|c|}
\hline Ingredient, \% & $\begin{array}{c}\text { Starter } \\
(1-21 \mathrm{~d})\end{array}$ & $\begin{array}{c}\text { Grower } \\
(22-35 \mathrm{~d})\end{array}$ \\
\hline Soybean meal & 51.15 & 47.69 \\
\hline Corn & 35.91 & 39.77 \\
\hline Soybean oil & 5.77 & 5.80 \\
\hline Dicalcium phosphate & 2.85 & 2.59 \\
\hline Limestone & 1.37 & 1.28 \\
\hline Rice husks meal (inert material) & 1.00 & 1.00 \\
\hline Sodium bicarbonate & 0.60 & 0.56 \\
\hline DL-Methionine & 0.39 & 0.35 \\
\hline Mycotoxin adsorbent & 0.30 & 0.30 \\
\hline Mineral premix ${ }^{1}$ & 0.15 & 0.15 \\
\hline Threonine & 0.13 & 0.11 \\
\hline L-Lysine $\mathrm{HCl}$ & 0.128 & 0.128 \\
\hline Vitamin premix ${ }^{2}$ & 0.10 & 0.10 \\
\hline \multirow[t]{2}{*}{ Total } & 100 & 100 \\
\hline & Starter & Grower \\
\hline $\mathrm{ME}, \mathrm{kcal} / \mathrm{kg}$ & 3.000 & 3.050 \\
\hline Crude protein (\%) & 28.00 & 26.00 \\
\hline Calcium (\%) & 1.40 & 1.30 \\
\hline Available phosphorus (\%) & 0.75 & 0.70 \\
\hline Lysine (\%) & 1.82 & 1.70 \\
\hline Methionine (\%) & 0.73 & 0.68 \\
\hline Methionine + Cystine (\%) & 1.18 & 1.11 \\
\hline Arginine (\%) & 1.95 & 1.82 \\
\hline Threonine (\%) & 1.16 & 1.09 \\
\hline
\end{tabular}

'Mineral enrichment per kg of feed: Cu: 15 mg; Fe: 65 mg; Mn: 110 mg; Zn: 100 mg; I: $1.5 \mathrm{mg}$; Se: $0.3 \mathrm{mg}$

${ }^{2}$ Vitamin enrichment per kg of feed: Vit A 11250 UI, Vit. D3: 4000 IU; Vit. E: 50 IU; Vit. K3: 4.5 mg. Biotin: 0.25 mg; Thiamine: 4.5 mg. Riboflavin B2: 8 mg; Pyridoxine: 7 mg; Vit. B12: 0.020 mg; Niacin: 75 mg. Pantothenic Acid: 23 mg; Folic Acid: 2 mg; Antioxidant: $15 \mathrm{mg}$.

diet not supplemented with additives and challenged with $\mathrm{SE}$; CE product (challenged): basal diet $+\mathrm{CE}$ product ( $10^{9} \mathrm{CFU} / \mathrm{kg}$ feed) and challenged with SE; OAB (challenged): basal diet + organic acid blend (2 g/kg feed) and challenged with SE; Lyncomycin (challenged): basal diet + antibiotic growth promoter (lincomycin, $44 \mathrm{mg} / \mathrm{kg}$ feed) and challenged with SE. Challenged and non-challenged poults were housed in separate rooms in the same building.

The antibiotic growth promoter applied was lincomycin at $44 \%$ (44 $\mathrm{mg}$ of active principle per $\mathrm{kg}$ of feed). The commercial organic acid blend was powdered and contained a balanced amount of shortand medium-chain fatty acids, including formic acid, acetic acid, sorbic acid, propionic acid, polysorbate, silicon dioxide, ammonium hydroxide, and coconut oil with guaranteed levels of: $37.4 \mathrm{~g}$ acetic acid $/ \mathrm{kg}, 73.6$ $\mathrm{g}$ formic acid/kg, and $377.1 \mathrm{~g}$ vegetable fatty acids/ $\mathrm{kg}$. The liquid commercial CE product was composed of non-specific intestinal microbiota from specific pathogen-free turkeys, with a minimum of $10^{6} \mathrm{CFU} /$
Use of Organic Acids and A Competitive Exclusion Product as Growth Promoter and Salmonella Enteritidis Control in Commercial Turkeys

$\mathrm{mL}$ and was sprayed on the diet after pelleting at a dose of $3 \mathrm{~mL} / \mathrm{kg}$ feed. The OAB was added to the diet at the expense of inert material (rice husks meal). None of the diets contained coccidiostats.

Two feed samples per treatment were collected, labeled but not identified, and submitted to the laboratory for detection of lactic-acid bacteria.

\section{Performance parameters}

Poults and feed were weighed per replicate (cage) on $\mathrm{d} 7,14,21$, and 28 to determine average body weight (BW), BW gain, and feed conversion ratio (FCR). BW gain and FCR were calculated for the entire experimental period ( $\mathrm{d}$ 0-28) and corrected for mortality.

\section{Cecal Salmonella Enteritidis enumeration}

At 20, 23, and $28 \mathrm{~d}$ of age, six turkey poults per treatment were randomly selected and euthanized. One of the ceca was removed, placed in a sterile plastic bag, weighed, and macerated with the aid of a spatula. The amount of PBS solution ( $\mathrm{pH} \mathrm{7.2)} \mathrm{added}$ to each sample was calculated, based on organ weight and contents, to achieve a ratio of $1: 10$, yielding a $10^{-1}$ dilution. After homogenizing the contents, $1 \mathrm{~mL}$ was removed to perform the remaining dilutions to $10^{-8}$ in test tubes containing $9 \mathrm{~mL}$ PBS (pH 7.2). A volume of $0.1 \mathrm{~mL}$ of each dilution was plated in duplicate on BGA Nal/Rif medium and then incubated at $41^{\circ} \mathrm{C}$ for $24 \mathrm{~h}$. The number of CFU/g of content and organ was converted to a $\log _{10}$ scale to interpret the results.

\section{pH Measurement of the Crop and Cecal Contents}

The crop and one of the ceca of the same birds sacrificed for SE enumeration were collected and placed on individual Petri dishes, out of which $1 \mathrm{~g}$ of the contents were removed. One $\mathrm{mL}$ deionized water was added, and after stirring for $1 \mathrm{~min}$, the $\mathrm{pH}$ was measured after mixture stabilization using a $\mathrm{pH}$ meter probe.

\section{Serum protein profiles}

On d 2, 5, and 10 post-challenge, blood samples were collected from the brachial vein of six poults per treatment. Blood samples were placed in test tubes, centrifuged $\left(1.500 \times \mathrm{xg}, 1 \mathrm{~min}, 10^{\circ} \mathrm{C}\right)$, and the obtained serum was stored at $-80^{\circ} \mathrm{C}$ and frozen until assayed for acute-phase protein (APP) levels as described below.

Serum protein levels were determined by the biuret method utilizing a commercial biochemistry kit Katal ${ }^{\circledR}$ 
Milbradt EL, Okamoto AS,

Padovani CR, Fascina VB, Silva TM,

Altarúgio R, Hataka A, Schmidt EMS,

Andreatti Filho RL

\section{Use of Organic Acids and A Competitive Exclusion Product as Growth Promoter and Salmonella Enteritidis Control in Commercial Turkeys}

(Interteck, Belo Horizonte, Brazil) and read using an automated spectrophotometer. The electrophoretic fractioning of the proteins in SDS-PAGE was performed by the technique described by Laemmli (1970) in a polyacrylamide gel matrix containing sodium dodecyl sulfate (SDS-PAGE). The estimated levels of serum protein fractions or peaks were determined via computer-assisted densitometry (CS $9301{ }^{\circledR}$, Shimadzu, Japan). Protein peaks were identified using reference markers (Sigma-Aldrich ${ }^{\circledR}$, Saint Louis, Missouri, EUA) with molecular weights of 20, 29, 36, 45, 55, 66, 97, 116 and $200 \mathrm{kDa}$. Also, the following purified proteins were used: ceruloplasmin $(C P, M W \pm 110$ $\mathrm{kDa}$ ), ovotransferrin (OVT, MW $\pm 70-75 \mathrm{kDa}$ ), albumin (Al, MW $\pm 62-65 \mathrm{kDa}$ ) and $\alpha 1$-acid glycoprotein (AGP, $\mathrm{MW} \pm 45 \mathrm{kDa})$.

\section{Statistical Analysis}

The experimental unit consisted of one individual bird. SE counts were $\log _{10}$ transformed to achieve normal distribution. Performance, $\mathrm{pH}$ measurement, and SE count results were submitted to analysis of variance, and means were compared by Tukey's test of multiple comparisons ( $0.05 \%$ probability levels). Means and standard errors of the mean (SEM) were calculated. The protein peak values obtained were submitted to the same procedures, except for the OVT fraction values, which were submitted to nonparametric analysis of variance for a model with two factors, and means were compared by Dunn's test for multiple comparisons (0.05\%) (Zar, 2010).

\section{RESULTS AND DISCUSSION}

The samples of the feed supplemented with the CE product contained $10^{7} \mathrm{CFU}$ of lactic acid bacteria/kg.

Initial (d 1) body weight was not different among the experimental treatments (Table 2). At $7 d$ of age, poults fed the diet containing $O A B$ presented lower BW $(p=0.031)$ and BWG $(p=0.042)$ compared with the poults of all other treatments, which corresponded to approximately 16\% lower BW (30 g) and 23\% lower BW gain (29 g) relative to the Negative Control group. No BW or BWG differences among treatments were detected at $d 14,21$ or 28 of age. The FCR was not affected by the treatments.

The inclusion rate and type of organic acid utilized may result in a decrease in feed intake, consequently, reductions in BW gain and BW. According to Cave (1984), propionic acid may reduce feed intake due to its influence on diet palatability, who observed that broiler chickens fed a diet supplemented with $6 \mathrm{~g}$

Table 2 - Mean BW, BW gain, and feed conversion ratio (FCR) of commercial turkeys fed a basal diet and diets with a competitive exclusion product (CE), an organic acid blend (OAB), or an antibiotic (Lincomycin), and orally challenged by gavage with $10^{8} \mathrm{CFU}$ Salmonella Enteritidis/bird at $18 \mathrm{~d}$ of age.

\begin{tabular}{|c|c|c|c|c|c|c|}
\hline \multicolumn{7}{|c|}{ Experimental Group1* } \\
\hline \multicolumn{7}{|l|}{ BW (g) } \\
\hline Initial & $61 \pm 0.7$ & $61 \pm 0.5$ & $62 \pm 0.6$ & $61 \pm 0.5$ & $62 \pm 0.5$ & 0.998 \\
\hline $7 d$ & $184 \pm 2.7 a$ & $179 \pm 2.7 a$ & $171 \pm 1,6 a b$ & $154 \pm 3.2 b$ & $188 \pm 1.9 a$ & 0.031 \\
\hline $14 d$ & $531 \pm 11.3$ & $516 \pm 17.9$ & $555 \pm 8.7$ & $542 \pm 18.1$ & $538 \pm 26.1$ & 0.095 \\
\hline $21 d$ & $831 \pm 19.7$ & $794 \pm 24.3$ & $792 \pm 30.1$ & $808 \pm 19.1$ & $856 \pm 30,1$ & 0.876 \\
\hline $28 d$ & $1200 \pm 32$ & $1175 \pm 33.9$ & $1250 \pm 49.8$ & $1144 \pm 33$ & $1245 \pm 56.3$ & 0.067 \\
\hline \multicolumn{7}{|c|}{ BW gain (g) } \\
\hline 0 to $\mathrm{d}$ & $122 \pm 0.7 a$ & $118 \pm 3.1 \mathrm{a}$ & $109 \pm 1.4 a b$ & $93 \pm 3.0 b$ & $126 \pm 1.7 a$ & 0.042 \\
\hline 0 to $21 \mathrm{~d}$ & $770 \pm 19$ & $732 \pm 24$ & $731 \pm 31$ & $746 \pm 19$ & $795 \pm 30$ & 0.233 \\
\hline 21 to $28 d$ & $374 \pm 11.3$ & $381 \pm 146$ & $458 \pm 82$ & $336 \pm 159$ & $389 \pm 61$ & 0.053 \\
\hline 0 to $28 \mathrm{~d}$ & $1138 \pm 24$ & $1113 \pm 32$ & $1189 \pm 49$ & $1082 \pm 34$ & $1184 \pm 56$ & 0.082 \\
\hline \multicolumn{7}{|c|}{ FCR ( $g$ of feed/g of BW) } \\
\hline 0 to $7 \mathrm{~d}$ & $1.16 \pm 0.05$ & $1.18 \pm 0.06$ & $1.26 \pm 0.01$ & $1.24 \pm 0.03$ & $1.22 \pm 0.02$ & 0.823 \\
\hline 0 to $21 \mathrm{~d}$ & $1.45 \pm 0.02$ & $1.55 \pm 0.02$ & $1.43 \pm 0.08$ & $1.60 \pm 0.04$ & $1.41 \pm 0.03$ & 0.239 \\
\hline 21 to $28 d$ & $1.58 \pm 0.06$ & $1.87 \pm 0.06$ & $1.76 \pm 0.03$ & $1.71 \pm 0.04$ & $1.52 \pm 0.03$ & 0.059 \\
\hline 0 to $28 \mathrm{~d}$ & $1.62 \pm 0.09$ & $1.71 \pm 0.09$ & $1.59 \pm 0.05$ & $1.64 \pm 0.05$ & $1.55 \pm 0.05$ & 0.751 \\
\hline
\end{tabular}

Values are expressed as mean \pm SEM.

$a, b$ Means followed by different letters in the same row are significantly different $(p<0.05)$.

${ }^{1}$ Negative Control: basal diet and no SE challenge; Positive Control: basal diet and SE challenge; CE: basal diet with CE product (10 ${ }^{9} \mathrm{CFU} / \mathrm{kg}$ feed) and SE challenge; OAB: basal diet with an organic acid blend ( $2 \mathrm{~g} / \mathrm{kg}$ of feed) and SE challenge; Lincomycin: basal diet with lincomycin (44 mg/kg feed) and SE challenge. The basal diet did not contain any growth promoter additive.

*All groups received one dose of SE challenge, except for the Negative Control group. 
Milbradt EL, Okamoto AS,

Padovani CR, Fascina VB, Silva TM,

Altarúgio R, Hataka A, Schmidt EMS,

Andreatti Filho RL

\section{Use of Organic Acids and A Competitive Exclusion Product as Growth Promoter and Salmonella Enteritidis Control in Commercial Turkeys}

propionic acid/kg reduced their feed intake and BW gain by 5.2 and $6.1 \%$, respectively, when compared with a diet with no propionic acid.

Although propionic acid was part of the blend of organic acids utilized in this study, its inclusion level was low (2 g/kg of the total OAB) when compared with levels that can cause feed intake reduction. Furthermore, at $14 \mathrm{~d}$ of age, the performance of the poults fed the diets containing the $O A B$ was similar to that of the poults under the other treatments. According to Cave (1982), poultry are capable of habituating to organic acids. None of the treatments exerted any positive effect on the growth performance parameters analyzed, even after the SE challenge.

In the present study, the treatments had no effect on the $\mathrm{pH}$ values of the crop and cecal contents measured at $\mathrm{d} 20,23$, and 28 of age. The mean $\mathrm{pH}$ of the crop and cecal contents were, respectively, $6.3( \pm 0.17)$ and $6.6( \pm 0.11)$ in the Negative Control group; 6.3 $( \pm 0.18)$ and $6.8( \pm 0.14)$ in the Positive Control group, $6.1( \pm 0.13)$ and $6.7( \pm 0.21)$ in the group fed the CE product, $6.1( \pm 0.18)$ and $6.5( \pm 0.21)$ in the group fed the $O A B$, and $6.2( \pm 0.17)$ and $6.8( \pm 0.18)$ in the group fed Lyncomycin. According to Gong et al. (2007), the crop is predominantly colonized by bacteria of the genus Lactobacillus, which produce lactic acid and, therefore, make the crop pH acidic. Although the EC product continuously fed to the birds was rich in lactic acid-producing bacteria, it did not contribute to a $\mathrm{pH}$ reduction of the crop content, nor the OAB.

According to Yamamoto et al. (1961), the cecum is one of the main reservoirs of Salmonella in commercial turkeys. Before the SE challenge, none of the drag swab samples was tested positive for Salmonella spp., and after challenge, all the poults of the experimental groups presented cecal SE colonization, except for those in the Negative Control group. On d 2 postchallenge, the diets supplemented with the CE product and with the OAB were capable of reducing SE colonization ( $p=0.029$; Table 3 ) relative to the Positive Control group.

Competitive exclusion has been employed as a prophylactic measure to increase the resistance of birds to infections by enteric pathogens by competing for binding sites in the intestinal epithelium (Schneitz, 2005) or by producing volatile fatty acids (van der Wielen et al., 2000). The diet supplemented with the CE product reduced SE CFU values by 1.9 and $2 \log _{10}$ units on $\mathrm{d} 2$ and 10 post-challenge, respectively, when compared with the Positive Control group. In a previous study, Milbradt et al. (2014) evaluated the efficacy of
Table 3 - Mean of $\log _{10}$ colony-forming units of Salmonella Enteritidis per gram of cecal content of turkeys orally inoculated with $10^{8} \mathrm{CFU} /$ bird at $18 \mathrm{~d}$ of age.

\begin{tabular}{lccc}
\hline \multirow{2}{*}{ Experimental Group ${ }^{1 *}$} & \multicolumn{4}{c}{ Age $(\mathrm{d})\left(\log _{10}\right.$ CFU of SE/g \pm SEM) } \\
\cline { 2 - 4 } & 20 & 23 & 28 \\
\hline Positive Control & $7.1 \pm 1.0 \mathrm{a}$ & $5.8 \pm 0.2 \mathrm{~b}$ & $4.2 \pm 0.5 \mathrm{~b}$ \\
CE product & $5.2 \pm 0.7 \mathrm{~b}$ & $4.3 \pm 0.4 \mathrm{ab}$ & $2.2 \pm 0.3 \mathrm{a}$ \\
OAB & $5.7 \pm 0.2 \mathrm{~b}$ & $4.0 \pm 0.3 \mathrm{a}$ & $1.8 \pm 0.2 \mathrm{a}$ \\
Lincomycin & $6.7 \pm 0.3 \mathrm{ab}$ & $3.8 \pm 0.6 \mathrm{a}$ & $1.9 \pm 0.1 \mathrm{a}$ \\
p-value & 0.029 & 0.037 & 0.048 \\
\hline
\end{tabular}

Values are mean \pm SEM.

$a-b$ Means followed by different letters in the same column are significantly different, Tukey's multiple comparison test $(p<0.05)$.

Positive Control: control diet and SE challenge; CE: Diet with CE product (109 CFU/kg feed) and SE challenge; OAB: Diet with an organic acid blend ( $2 \mathrm{~g} / \mathrm{kg}$ of feed) and SE challenge; Lincomycin: Diet with lincomycin (44 mg/kg feed) and SE challenge

${ }^{1}$ Evaluations were performed on 6 poults per experimental group.

${ }^{*}$ All groups received one dose of SE challenge.

the same product in commercial turkeys challenged with SE immediately before slaughter (90 d of age). The birds continuously fed a diet supplemented with the CE product presented greater population of Lactobacillus spp., lower number of bacteria of the Enterobacteriaceae family, and higher cecal butyric acid concentrations than those fed a control diet. This positive effect of the CE product and its metabolites on the cecal microbiota may have caused to the observed reduction in the incidence of SE and of SE CFU values in the cecal content compared with the Positive Control group (birds challenged and fed the control diet).

According to Thompson \& Hinton (1997), organic acids fed in the powdered form are rapidly absorbed in the intestinal tract, and therefore, do not reach the cecum. In the present study, the diet supplemented with OAB reduced the SE CFU values by 1.4 and 2.4 $\log _{10}$ units on $\mathrm{d} 2$ and 10 post-challenge, respectively, when compared with the Positive Control group.

The mechanism by which antibiotic growth promoters improve animal performance has not been fully elucidated yet; however, there are studies focusing on the interaction between antibiotics and the intestinal microbiota (Dibner \& Richards, 2005). Two days post-challenge, the CFU value $\left(6.7 \log _{10}\right)$ obtained in the poults fed the diet containing lincomycin was not different from that of the Positive Control group $\left(7.1 \log _{10}\right)$. This result may be attributed to the high dose of inoculum used to challenge the birds and the brief time interval between challenge and sampling, as on $\mathrm{d} 5$ post-challenge, there was a reduction of $2 \log _{10}$ units in the CFU of the SE in the group of birds fed the diet containing lincomycin. 
Milbradt EL, Okamoto AS,

Padovani CR, Fascina VB, Silva TM,

Altarúgio R, Hataka A, Schmidt EMS,

Andreatti Filho RL

\section{Use of Organic Acids and A Competitive Exclusion Product as Growth Promoter and Salmonella Enteritidis Control in Commercial Turkeys}

Acute-phase proteins (APPs) are proteins of hepatic origin, and their blood concentrations significantly change during microbial infections and physical trauma (Gruys et al., 2006). The identification of APPs has been employed to monitor the health status of liverstock, including poultry (Juul-Madsen et al., 2003; Eckersall, 2004; Petersen et al., 2004). Blood APP concentrations are often proportional to the antigenic stimulus and can be detected for long periods of time (Eckersall \& Bell, 2010). In the present study, the treatments and the SE challenge influenced the estimated OVT and AGP serum levels, but no effect was observed on CP or Al levels (Table 4).

In birds, OVT is a positive APP (Xie et al., 2002a; O'Reilly \& Eckersall, 2014), that is, its serum levels increase during infections, inflammatory processes, and when there is tissue damage. A difference in the serum OVT levels was observed on d 5 post-challenge, when the poults fed the diet containing lincomycin presented higher levels than those in the other experimental groups $(p=0.038)$. At the same time ( $d$ 5 post-challenge), SE CFU values of the cecal content were reduced relative to $\mathrm{d} 2$ post-challenge, also in the Positive Control group. According to Xie et al. (2002b), OVT is an antibacterial protein capable of sequestering and storing iron, which is essential for bacterial growth. Furthermore, it is believed that OVT exerts a specific action on Gram-negative bacteria due to its ability to permeate the external membrane of such bacteria, thus causing bacteriostasis (Aguilera et al., 2003). On d 10 post-challenge (at $28 d$ of age), serum OVT levels increased in the Positive Control group (196.7 mg/dL) and in those fed the CE product $(188.5 \mathrm{mg} / \mathrm{dL})$, and were statistically similar to those observed in the poults that received lincomycin in the diet $(173.5 \mathrm{mg} / \mathrm{dL})$. There was no increase in serum OVT levels in poults in the Negative Control group $(45.4 \mathrm{mg} / \mathrm{dL})$ or in those that fed $O A B(40.7 \mathrm{mg} / \mathrm{dL})$, and these levels remaining stable throughout the period investigated.

The $\alpha 1$-acid glycoprotein (AGP) is one of the most widely measured acute-phase protein in chickens due to the commercial availability of specific kits for this poultry species (O'Reilly \& Eckersall, 2014). AGP plays an important role in the early stages of inflammation and infection in birds (Murata et al., 2004). Among the treatments in the present study, serum AGP levels differed only on $d 10$ post-SE challenge $(p=0.032)$, when the poults challenged and fed the control diet (Positive Control) presented higher serum AGP level $(8.0 \mathrm{mg} / \mathrm{dL})$ than those under the other treatments (Negative Control: $4.6 \mathrm{mg} / \mathrm{dL}, \mathrm{CE}$ product: $2.8 \mathrm{mg} / \mathrm{dL}$, OAB: $4.4 \mathrm{mg} / \mathrm{dL}$, Lincomycin: $3.4 \mathrm{mg} / \mathrm{dL}$ ). Although all the challenged birds presented a high SE contamination level $\left( \pm 6.2 \log _{10}\right)$, this appears to not have been sufficient to raise the AGP levels, at least until d 5 post-challenge. The results are consistent to those presented by Holt \&

Table 4 - Serum acute-phase protein levels $(\mathrm{mg} / \mathrm{dL}$ ) of commercial turkeys fed a basal diet and diets with a competitive exclusion product (CE), an organic acid blend (OAB), or an antibiotic (Lincomycin), and orally challenged by gavage with $10^{8}$ CFU Salmonella Enteritidis/bird at $18 \mathrm{~d}$ of age.

\begin{tabular}{|c|c|c|c|c|c|c|c|}
\hline \multicolumn{8}{|c|}{ Experimental Group ${ }^{1 *}$} \\
\hline Item (mg/dL) & $\begin{array}{l}\text { Age } \\
\text { (d) }\end{array}$ & Negative Control & Positive Control & CE product & $O A B$ & Lincomycin & $p$-value \\
\hline \multirow[t]{3}{*}{ Ceruloplasmin } & 20 & $8.4 \pm 0.3$ & $6.5 \pm 0.6$ & $7.2 \pm 3.1$ & $7.6 \pm 1.1$ & $9.2 \pm 0.4$ & 0.096 \\
\hline & 23 & $7.5 \pm 0.9$ & $7.1 \pm 0.6$ & $7.6 \pm 0.7$ & $7.9 \pm 0.7$ & $8.3 \pm 0.8$ & 0.858 \\
\hline & 28 & $9.2 \pm 1.3$ & $7.6 \pm 0.9$ & $6.6 \pm 0.8$ & $6.5 \pm 1.2$ & $5.6 \pm 0.5$ & 0.240 \\
\hline \multirow[t]{3}{*}{${ }^{++}$Ovotransferrin } & 20 & $39.2(26 ; 67) a$ & $34.4(29 ; 84) a$ & $45.8(33 ; 66) a$ & $36.6(30 ; 48) a$ & $40.1(25 ; 71) a$ & 0.652 \\
\hline & 23 & $38.9(28 ; 79) b$ & $43.4(26 ; 68) b$ & $41.1(33 ; 57) b$ & $36.6(31 ; 45) b$ & $168.5(36 ; 292) a$ & 0.038 \\
\hline & 28 & $45.4(24 ; 68) b$ & $196.7(167 ;$; 273)а & $188.5(136 ; 215) a$ & $40.7(23 ; 79) b$ & $173.5(69 ; 293) a$ & $<0.001$ \\
\hline \multirow[t]{3}{*}{ Albumin } & 20 & $1369 \pm 32$ & $1195 \pm 51$ & $1259 \pm 89$ & $1354 \pm 68$ & $1348 \pm 57$ & 0.235 \\
\hline & 23 & $1330 \pm 94$ & $1265 \pm 77$ & $1355 \pm 27$ & $1336 \pm 79$ & $1356 \pm 38$ & 0.851 \\
\hline & 28 & $1431 \pm 61$ & $1332 \pm 75$ & $1373 \pm 35$ & $1475 \pm 88$ & $1383 \pm 91$ & 0.819 \\
\hline \multirow{3}{*}{$\begin{array}{l}\alpha 1 \text {-acid } \\
\text { Glycoprotein }\end{array}$} & 20 & $4.4 \pm 0.3$ & $3.7 \pm 0.5$ & $4.3 \pm 0.8$ & $3.5 \pm 0.6$ & $5.1 \pm 0.8$ & 0.454 \\
\hline & 23 & $4.2 \pm 0.9$ & $5.7 \pm 0.6$ & $4.6 \pm 0.2$ & $4.7 \pm 0.3$ & $5.4 \pm 0.8$ & 0.468 \\
\hline & 28 & $4.6 \pm 0.9 b$ & $8.0 \pm 1.0 a$ & $2.8 \pm 0.8 b$ & $4.4 \pm 1.3 b$ & $3.4 \pm 0.3 b$ & 0.032 \\
\hline
\end{tabular}

Values are mean \pm SEM, except for the protein ${ }^{++}$Ovotransferrin, whose values are expressed as median (minimum value; maximum value).

${ }^{++}$Medians followed by different lowercase letters in the same column are significantly different by Dunn's multiple comparison test $(p<0.05)$.

${ }^{a-b}$ Means followed by different letters in the same column are significantly different, Tukey's multiple comparison test $(p<0.05)$.

${ }^{1}$ Negative Control: control diet and no SE challenge; Positive Control: control diet and SE challenge; CE: Diet with CE product (109 CFU/kg feed) and SE challenge; OAB: Diet with an organic acid blend ( $2 \mathrm{~g} / \mathrm{kg}$ of feed) and SE challenge; Lincomycin: Diet with lincomycin ( $44 \mathrm{mg} / \mathrm{kg}$ feed) and SE challenge. The control diet did not contain any growth promoter additive.

${ }^{*}$ All groups received one dose of SE challenge, except the birds of Negative Control group. 
Milbradt EL, Okamoto AS,

Padovani CR, Fascina VB, Silva TM,

Altarúgio R, Hataka A, Schmidt EMS,

Andreatti Filho RL

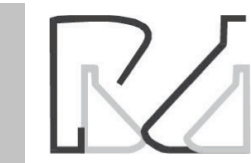

Use of Organic Acids and A Competitive Exclusion

Product as Growth Promoter and Salmonella

Enteritidis Control in Commercial Turkeys
Gast (2002), who challenged laying hens submitted or not to induced molting using SE, and measured their serum AGP levels. Those authors reported that even in the birds presenting high SE cecal contamination $\left(6.8 \log _{10}\right)$, their serum AGP levels were not different from those of the non-contaminated birds. And yet in another experiment within the same study, Holt \& Gast (2002) verified that the serum AGP levels of SE-infected birds increased in a later phase of the infection, as found in the present study, and not in the initial phase, as reported in the literature (Nakamura et al., 1988; Takanashi et al., 1988).

\section{CONCLUSIONS}

1. The inclusion levels of organic acids in starter diets should be low, since they can negatively influence the growth performance of commercial turkeys.

2. The additives that promote similar results as those of antibiotics under controlled experimental conditions should be further evaluated on commercial farms to allow their utilization under practical conditions.

3. Supplementing commercial turkey diets with the evaluated $O A B$ and $C E$ product may reduce $S E$ load, potentially leading to lower contamination risk during the rearing period.

4. Serum OVT and AGP levels can be used as effective and fast indicators of infection, including that by SE.

\section{ACKNOWLEDGMENTS}

The authors thank the Sao Paulo State Foundation for Research Support for financing the project (process number 2010/20655-3) and for granting the doctoral scholarship to the first author (process number 2011/07752-2).

\section{REFERENCES}

Aguilera O, Quiros LM, Fierro JF. Transferrins selectively cause ion efflux through bacterial and artificial membranes. FEBS Letters 2003;548(13):5-10.

Andreatti Filho RL, Silva EN, Curi PR. Ácidos orgânicos e microbiota cecum anaeróbia no controle da infecção experimental de frangos por Salmonella Typhimurium e Salmonella Enteritidis. Arquivo Brasileiro de Medicina Veterinária e Zootecnia 1997;49(6):661-672.

Aviagen. Commercial management guidelines. 2015. Available from: http://www.aviagenturkeys.com/performance-objectives .

AVMA - American Veterinary Medical Association. Guidelines on euthanasia. Schaumburg: American Veterinary Medical Association; 2007. 36p.
Cave NAG. Effect of dietary short and medium-chain fatty acids on feed intake by chicks. Poultry Science 1982;61(6):1147-1153.

Cave NAG. Effect of dietary propionic and lactic acids on feed intake by chicks. Poultry Science 1984;63(1):131-134.

CDC - Centers for Disease Control and Prevention Foodborne. Antibiotic resistance threats in the United States; 2013. Available from: https:// www.cdc.gov/drugresistance/pdf/ar-threats-2013-508.pdf.

Dibner JJ, Richards JD. Antibiotic growth promoters in agriculture: history and mode of action. Poultry Science 2005;84(4):634-643.

Eckersall PD. The time is right for acute phase protein assays. The Veterinary Journal 2004;168(1):3-5.

Eckersall PD, Bell R. Acute phase proteins: biomarkers of infection and inflammation in veterinary medicine. The Veterinary Journal 2010;185(1):23-27

Gong J, Si W, Forster RJ, Huang R, Yu H, Yin Y, et al. 16S rRNA gene-based analysis of mucosa-associated bacterial community and phylogeny in the chicken gastrointestinal tracts: from crops to cecum. FEMS Microbiology Ecology 2007;59(1):147-157

Goren E, Jong WA, Doornenbal P, Koopman JP, Kennis HM. Protection of chicks against salmonella infection induced by spray application of intestinal microflora in the hatchery. Veterinary Quarterly 1984;6(2):7379.

Gruys E, Toussaint MJM, Niewold TA, Koopmans SJ, van Dijk E, Meloen RH. Monitoring health by values of acute phase proteins. Acta Histochemica 2006;108(3):229-232.

Juul-Madsen HR, Munch M, Handberg KJ, Sørensen P, Johnson AA, Norup $L R$, et al. Serum levels of mannan-binding lectin in chickens prior to and during experimental infection with avian infectious bronchitis virus. Poultry Science 2003;82(2):235-241.

Holt PS, Gast RK. Comparison of the effects of infection with Salmonella Enteritidis, in combination with an induced molt, on serum levels of the acute phase protein, $\alpha-1$ acid glycoprotein, in hens. Poultry Science 2002;81(9):1295-1300.

Laemmli UK. Cleavage of structural proteins during the assembly of the head of bacteriophage T4. Nature 1970;227(5259):680-685.

Mallinson ET, Snoeyenbos GH. Salmonellosis. In: Purchase HG, Arp LH, Domermuth $\mathrm{CH}$, Pearson JE, editors. A laboratory manual for the isolation and identification of avian pathogens. $3^{\text {rd }}$ ed. Kennett Square: American Association of Avian Pathologists, University of Pennsylvania;1989. p.3-11

Milbradt EL, Zamae JR, Araújo Júnior JP, Mazza P, Padovani CR, Carvalho VR, et al. Control of Salmonella Enteritidis in turkeys using organic acids and competitive exclusion product. Journal Applied Microbiology 2014; 117(2):554-563.

Murata $H$, Shimada N, Yoshioka M. Current research on acute phase proteins in veterinary diagnosis: an overview. The Veterinary Journal 2004; 168(1):28-40.

Nakamura K, Mitarai Y, Yoshioka M, Koizumi N, Shibahara T, Nakajima Y. Serum levels of interleukin-6, $\alpha$-1-acid glycoprotein, and corticosterone in two-week-old chickens inoculated with Escherichia coli lipopolysaccharide. Poultry Science 1998;77(6):908-911.

NRC - National Research Council. Nutrient requirements of poultry. $9^{\text {th }}$ ed Washington: National Academy Press; 1994.

O'Reilly EL, Eckersall PD. Acute phase proteins: a review of their function, behaviour and measurement in chickens. World's Poultry Science Journal 2014;70(1):27-44 
Milbradt EL, Okamoto AS,

Padovani CR, Fascina VB, Silva TM,

Altarúgio R, Hataka A, Schmidt EMS,

Andreatti Filho RL
Petersen $\mathrm{HH}$, Nielsen JP, Heegard PMH. Application of acute phase protein measurements in veterinary clinical chemistry. Veterinary Research 2004;35(2):163-187

Schneitz C. Competitive exclusion in poultry: 30 years of research. Food Control 2005;16(8):657-667.

Sun $X$, McElroy A, Webb Jr KE, Sefton AE, Novak C. Broiler performance and intestinal alterations when fed drug-free diets. Poultry Science 2005;84(8):1294-1302.

Van der Wielen PWJJ, Biesterveld S, Notermans S, Hofstra H, Urlings BAP, Van Knapen F. Role of volatile fatty acids in development of the cecum microflora in broiler chickens during growth. Applied and Environmental Microbiology 2000;66(6):2536-2540.

Van Immerseel F, Russell JB, Flythe MD, Gantois I, Timbermont L, Pasmans $F$, et al. The use of organic acids to combat Salmonella in poultry: a mechanistic explanation of the efficacy. Avian Pathology 2006;35(3):182-188

Takahashi K, Miyake N, Ohta T, Akiba T, Tamura K. Changes in plasma $\alpha$-1-acid glycoprotein concentration and selected immune response in
Use of Organic Acids and A Competitive Exclusion

Product as Growth Promoter and Salmonella

Enteritidis Control in Commercial Turkeys

broiler chickens injected with Escherichia coli lipopolysaccharide. British Poultry Science 1998;39(1):152-155.

Thompson JL, Hinton M. Antibacterial activity of formic and propionic acids in the diet of hens on Salmonella in the crop. British Poultry Science 1997;38(1):59-65

Xie H, Huff GR, Huff WE, Balog JM, Holt P, Rath NC. Identification of ovotransferrin as an acute phase protein in chickens. Poultry Science 2002a;81(1):112-120.

Xie H, Newberry L, Clark FD, Huff WE, Huff GR, Balog JM, et al. Changes in serum ovotransferrin levels in chickens with experimentally induced inflammation and diseases. Avian Diseases 2002b;46(1):122-131.

Yamamoto R, Adler HE, Sadler WW, Stewart GF. A study of Salmonella Typhimurium infection in market age turkeys. American Journal of Veterinary Research 1961;22:382-387.

Zar JH. Biostatistical analysis. $5^{\text {th }}$ ed. Upper Saddle River: Prentice-Hall/ Pearson; 2010. 